\title{
PEMODELAN E-COMMERCE BERBASIS WEB MENGGUNAKAN CONTENT MANAGEMENT SYSTEM
}

\author{
Rinto Prasetyo Adi ${ }^{*}$, Gandung Triyono ${ }^{2}$ \\ ${ }^{12}$ Fakultas Teknologi Informasi, Program Studi Sistem Informasi, Universitas Budi Luhur, Jakarta, Indonesia \\ Email: ${ }^{1 *}$ prasetyoadi.rinto@gmail.com, ${ }^{2}$ gandung.triyono@budiluhur.ac.id \\ (* : coressponding author)
}

\begin{abstract}
Abstrak-Pengembangan e-commerce memungkinkan sebuah bisnis berlangsung secara daring baik itu untuk kegiatan penjualan, pembelian, ataupun pemasaran. E-commerce mempu menyediakan informasi yang paling terkini mengenai produk atau jasa yang disediakan. Pembatasan Sosial Berskala Besar ( $\underline{\text { PSBB}}$ ) dalam rangka mencegah penyebaran virus covid-19 mengakibatkan penurunan daya beli masyarakat. Hal ini langsung berdampak pada pelaku usaha, salah satunya adalah toko Loro Blonyo, toko ini merupakan usaha kecil yang bergerak dalam bidang penjualan dan pemasaran pakaian dan kerajinan batik. Diperlukan model e-commerce berbasis web untuk mengatasi permasalahan pada toko Loro Blonyo, mengingat pada saat ini telah terjadi pergeseran pola atau kebiasaan masyarakat dalam berbelanja dari offline ke online. Model e-commerce berbasis web dikembangkan dengan menggunakan CMS dan BMS. CMS digunakan untuk mengembangkan mode ecommerce berbasis web dan BMS digunakan untuk menganalisis sistem berjalan dan mengidentifikasi kebutuhan sistem yang dikembangkan. Hasil penelitian ini adalah mendapatkan model e-commerce yang sesuai dengan kebutuhan toko Loro Blonyo. Model e-commerce berbasis web yang dikembangkan telah diuji langsung ke user, hasil pengujian yang didapatkan adalah cukup bagus.
\end{abstract}

Kata Kunci: e-commerce, pemodelan, CMS, BMC, wordpress

\begin{abstract}
The development of e-commerce allows a business to take place online, be it for sales, buying, or marketing activities. E-commerce will enable you to provide the most up-to-date information about the products or services provided. Pembatasan Sosial Bersekala Besar (PSBB) aims to prevent the spread of the Covid-19 virus resulted in a decrease in people's purchasing power. This time immediate impact on business actors, one of which is business actors. One of them is the Loro Blonyo shop. This shop is a small business engaged in the sale and marketing of clothing and batik crafts. The webbased e-commerce model is the right solution to solve problems at Loro Blonyo stores, considering that there has been a shift in people's patterns or habits in shopping from offline to online. The web-based e-commerce model developed using CMS and BMS. CMS is used to create a web-based e-commerce model, and BMS is used to analyze the running system and identify the system's requirements. The research result is to produce an e-commerce model that suits the needs of Loro Blonyo stores. The web-based e-commerce model developed has been tested directly on the user; the test results are quite good.
\end{abstract}

Keywords: , e-commerce, modeling, CMS, BMC, wordpress

\section{PENDAHULUAN}

Dunia telah memasuki era digital dengan perkembangan teknologi informasi yang sedemikian pesatnya. Perkembangan teknologi informasi ini bahkan telah merambah ke semua bidang usaha termasuk usaha retail. Sistem yang terkomputerisasi di berbagai bidang menjadi kebutuhan, pengolahan data secara elektronik atau digitalisasi menjadi hal penting yang perlu diperhatikan dalam kegiatan usaha. Digitalisasi telah mengubah tatanan bisnis tradisional yang selama ini dijalankan oleh penggiat dunia usaha. Hal tersebut, mengharuskan setiap usaha diwajibkan dan dituntut untuk terus mengembangkan potensi teknologi informasi agar tidak tertinggal dari usahausaha lain yang sudah terlebih dahulu memanfaatkannya.

Salah satu penerapan teknologi informasi di dunia usaha adalah e-commerce atau electronic commerce. Ecommerce memungkinkan semua transaksi dilakukan secara daring baik itu penjualan, pembelian, ataupun pemasaran menggunakan sistem yang sudah terintegrasi secara digital dan menyediakan informasi yang paling terkini atau terbaru mengenai produk atau jasa yang disediakan [1].

Pandemi yang disebabkan Covid-19 berdapak di berbagai sector. Selain sektor kesehatan, sektor ekonomi juga mengalami dampak serius. Pembatasan aktivitas masyarakat berpengaruh pada aktivitas bisnis yang kemudian berimbas pada perekonomian [2]. Dengan diterapkanya PSBB sangat mempengaruhi sektor bisnis khususnya penjualan dan pemasaran, salah satunya yang kena dampak adalah Toko Loro Blonyo.

Loro Blonyo merupakan sebuah usaha kecil menengah yang bergerak dalam bidang penjualan dan pemasaran fashion dan kerajinan batik yang berdiri sejak tahun 2019 dan menyewa sebuah lapak atau toko di 
Rest Area KM 260 Brebes, Jawa Tengah. Selama ini Loro Blonyo tidak melakukan penjualan secara daring dan hanya mengandalkan penjualan yang menggunakan sistem tradisional yaitu penjualan luring atau penjualan secara langsung di tempat. Dengan cara penjualan seperti ini, Loro Blonyo otomatis hanya mengandalkan kedatangan konsumen yang datang ke toko. Hasil analisa yang telah dilakukan didapatkan informasi bahwa dengan adanya Toko PSBB Loro Blonyo mempunyai masalah yang serius, yaitu menurunya penjualan setiap bulananya. Analisa yang dilakukan dengan Business Model Canvas (BMC). Hasil analisa lainya, bahwa toko Loro Blonyo memiliki keterbatasan ruang lingkup dan kekurangan media informasi untuk masyarakat luas. Hal ini menyulitkan pihak toko untuk memperluas jaringan pelanggan.

Beberapa penelitian telah mencoba menyelesaikan masalah yang ada dengan mengembangkan model $e$ commerce. Beberapa mode e-commerce telah dikembangkan oleh [1], [2]-[5]. Penelitian yang dilakukan oleh [1], telah menyelesaikan masalah pada Konveksi Gamis Tawakal. Kemudian, [3] telah melakukan pengembangan e-commerce pada Distro ID Clothing. Penelitian [4] mengembangkan e-commerce untuk memperluas jangkauan pasar Pada Toko Batik Marissa. Dan penelitian [5] mengembangkan e-commerce untuk menyelesaikan masalah pada Toko Chipindwear. Namun demikian, penelitian-penelitian tersebut belum sampai pada tahap implementasi. Hal ini yang menjadi tantangan pada penelitian ini untuk mengembangkan model ecommerce sampai dengan implementasinya.

Berdasarkan masalah dan penelitian sebelumnya, maka penelitian ini mengembangkan model sistem ecommerce berbasis web. Pengembangan model digunakan framework Content Management System (CMS) Wordpress. Dalam mengidentifikasi kebutuhan guna pemnegembangan model sistem e-commerce digunakan pendekatan BMC. Model sistem e-commerce yang dikembangkan telah didiuji dengan cara mengimplementasikan dilapangan. E-commerce dapat dilihat di laman https://loroblonyo.id/. Laman tersebut telah dilakukan mengoptimasi dengan Search Engine Optimization (SEO) untuk mempercepat proses pengenalan toko ke masyarakat luas. Hasil dari pengembangan model sistem $e$-commerce mendapat apresiasi yang baik dari manajemen Toko Loro Blonyo.

\section{METODOLOGI}

E-Commerce merupakan perdagangan yang dilakukan secara elektronik, yang meliputi proses penyebaran, pembelian, penjualan, pemasaran barang dan jasa melalui sistem elektronik seperti internet, televisi, atau jaringan komputer lainnya [6]. Keunggulan dari e-commerce adalah dapat menjangkau pelanggan lebih luas yaitu di seluruh dunia, penghematan biaya operasional. Selain itu, konsumen dapat memiliki lebih banyak pilihan barang dan jasa dengan akses penuh selama 24 jam. Konsumen juga bisa diuntungkan dengan adanya perbandingan harga secara langsung [7].

Menurut [8], komponen-komponen pada e-commerce sebagai berikut: (1) Konsumen, konsumen merupakan pengguna internet yang menjadi target pasar yang potensial untuk diberikan berbagai macam penawaran baik berupa produk, jasa, maupun informasi oleh penjual. (2) Penjual, penjual adalah pihak yang menawarkan produk, jasa atau informasi kepada para konsumen baik secara individu maupun organisasi. (3) Produk, produk merupakan barang atau jasa yang ditawarkan dalam bentuk digital karena konsumen tidak melihat secara langsung dalam bentuk fisik. (4) Infrastruktur, infrastruktur meliputi penggunaan perangkat keras, perangkat lunak, dan juga sistem jaringan komputer seperti penggunaan jaringan komunikasi internet. (5) Frontend, frontend merupakan bagian antarmuka website yang berinteraksi langsung dengan user atau pengguna. (6) Backend, backend adalah bagian tampilan layar untuk admin website yang menjadi pusat proses pengaturan yang secara tidak langsung berperan sebagai pendukung antarmuka pada frontend. (7) Partner Bisnis, partner bisnis adalah pihak yang akan melakukan kerjasama ataupun kolaborasi dengan para produsen. Contoh dari partner bisnis ini misalnya seperti bank yang melakukan kerjasama dengan pihak ketiga penyedia payment gateway yang memudahkan konsumen melakukan pembayaran baik melalui transfer ataupun mobile banking.

Menurut [9] terdapat beberapa jenis e-commerce, yaitu: (1) Business to Business (B2B), B2B merupakan transaksi bisnis antara pelaku bisnis dengan pelaku bisnis lainnya. Dapat berupa kesepakatan spesifik yang mengandung kelancaran bisnis. (2) Business to Customer (B2C), B2C merupakan transaksi bisnis dan aktivitas yang dilakukan produsen kepada konsumen secara langsung. (3) Customer to Business (C2B), C2B adalah model bisnis di mana konsumen atau individu menciptakan nilai dan perusahaan mengkonsumsi nilai akan proses bisnis. (4) Customer to Customer (C2C), C2C merupakan aktivitas bisnis (penjualan) yang dilakukan oleh individu (konsumen) kepada individu (konsumen) lainnya. (5) Business to Government (B2G), B2G merupakan turunan dari B2B, perbedaannya proses ini terjadi antara pelaku bisnis dan instansi pemerintah. (6) Government to Customer (G2C), G2C merupakan hubungan atau interaksi antara pemerintah dan masyarakat. Konsumen dalam hal ini masyarakat, dapat dengan mudah menjangkau pemerintah sehingga memperoleh kemudahan dalam 
INDONESIA JOURNAL INFORMATION SYSTEM (IDEALIS)

Volume 4, Nomor 2, Juli 2021

ISSN 2684-7280 (online)

Halaman 187-196

available online at http://jom.fti.budiluhur.ac.id/index.php/IDEALIS/index

pelayanan sehari-hari. Dalam model sistem e-commerce yang dikembangkan merupakan pengembangan dari jenis model B2C.

Dalam memperlancar penelitian yang dilakukan maka dikembangkan atau dibuat tahapan penelitian atau metodologi. Tahapan penelitian yang digunakan dituangkan dalam bentuk diagram, lihat Gambar 1.

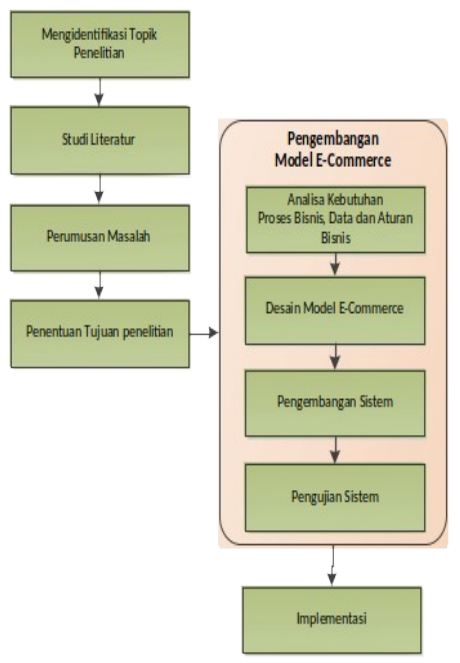

Gambar 1. Metodologi penbembangan ecommerce

Pada Gambar 1 diperlihatkan bahwa setelah melakukan penentuan masalah dan tujuan penelitian maka tahapan penelitian yang dilakukan adalah:

a. Analisa Kebutuhan

Pada tanap ini dilakukan analisa kebutuhan untuk pengembangan model e-commerce, kegiatan ini meliputi anlisa proses sistem berjalan, data dan aturan bisnis yang berlaku di perusahaan. Dalam proses analisa kebutuhan menggunakan model BMC. BMC merupakan kerangka kerja yang banyak digunakan untuk mendefinisikan model bisnis startup. BMC disusun dengan tujuan untuk menjelaskan, menilai, memvisualisasikan, serta mengubah model bisnis sehingga kinerja yang dihasilkan oleh startup lebih maksimal. Model bisnis ini bisa diterapkan oleh semua jenis startup tanpa terbatas sektor usaha [10].

Pada tahap ini dilakukan wawancara dengan pihak toko dan pengamatan di lapangan untuk memahami sistem kondisi sistem berjalan dan mengidentifikasi kebutuhan untuk pengembangan sistem. Idenfitikasi kebutuhan ini sebagai acuan dalam pengembangan model e-commerce khususnya pada saat desain model.

b. Desain Model E-Commerce

Bedasarkan hasil indentifikasi kebutuhan di digunakan untuk mengembangan model e-commerce. Model ecommerce dikembangkan dengan bahasa desain yaitu UML. Beberapa diagram yang terdapat di UML digunakan untuk memvisualisasi model seperti use cace diagram dan class diagram.

c. Pengembangan Sistem

Hasil desain mode e-commerce digunakan untuk pengembangan sistem. Sistem e-commerce dikembangkan dengan framework Content Management System (CMS). CMS merupakan aplikasi berbasis web yang digunakan untuk mengatur konten website, hampir semua website memiliki CMS yang mengatur kontennya, kecuali website statis. Sebuah CMS biasanya memiliki kemampuan untuk meng-update artikel, mengedit halaman website, mengatur menu, dan tampilan website [11].

Beberapa macam CMS yang sering digunakan untuk pengembangan sistem seperti WordPress, Joomla, Drupal, Aura,OpenCart, Prestashop, Moodle dan vBulletin. CMS WordPress, OpenCart dan Joomla merupakan CMS yang sering digunakan untuk pengembangan e-commerce. Pada penelitian ini menggunakan Wordpress untuk pengembangan sistem e-commber berasis web.

d. Pengujian Sistem

Pengujian yang dilakukan adalah menggunakan teknik blackbox testing dan pengujian ke user. Blackbox testing dilakukan pada saat pengembangan sistem. Blackbox testing dilakukan dihadapat pembimbing, yaitu menguji fungsi pada model e-commerce yang ada. Pengujian ini menggunakan dokumen atau data dari lapangan. Kemudian, pengujian pada user adalah pengujian yang dilakukan setelah sistem e-commerce dipasang atau diterapakan di https://loroblonyo.id/.

e. Implementasi Sistem 
Setelah model setelsai dikembangkan tahap terakhir adalah mmplementasikan model e-commerce. Implementasi dari model e-commerce ini dilakukan pada link https://loroblonyo.id/. setelah berhasil di implementasikan pada website maka tahap selanjutnya adalah mengoptimalkan kinerja dari web site itu sendiri. Pengoptimalan website ini menggunakan SEO. SEO merupakan kependekan dari Search Engine Optimization, SEO merupakan sekumpulan strategi untuk meningkatkan keberadaan dan visibilitas sebuah website di halaman hasil mesin pencari atau Search Engine Result Page (SERP). Semakin tinggi posisi dan semakin banyak sebuah situs muncul di halaman hasil mesin pencari, maka akan makin banyak pengunjung yang datang melalui mesin pencari tersebut. Pentingnya SEO didasari oleh fakta bahwa banyak situs yang memperoleh mayoritas kedatangan pengunjung atau web traffic-nya melalui hasil organik yang didapatkan dari mesin pencari [12]

\section{HASIL DAN PEMBAHASAN}

\subsection{Hasil Analisa}

Business Model Canvas (BMC) Setelah mendapatkan data-data yang diperoleh melalui proses wawancara dengan pihak pengelola toko Loro Blonyo. Hasil analisa sistem berjalan dan identifikasi kebuthunan dituangkan dalam kerangka BMC. Hasil dari analisa ini dapat dilihat pada Gambar 2.

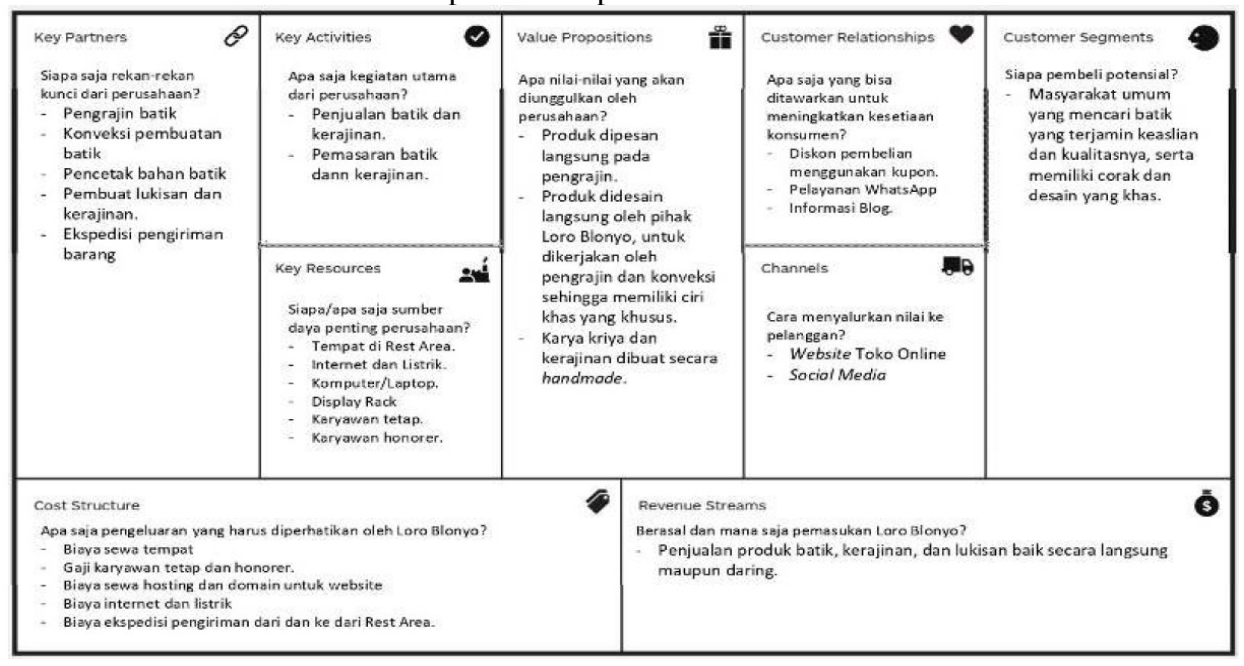

Gambar 2. Hasil analisa model bisnis pada Toko Loro Blonyo menggunakan BMC

Pada Gambar 2 diperlihatkan bahwa hasil analisa menunjukan beberapa komponen pada toko Loro Blonyo dapat dinaikan nilainya. Penjelasan dari beberapa komponen sbb:

a. Customer Segments

Customer segments atau segmentasi pelanggan memberikan gambaran mengenai siapa saja pembeli potensial dari toko batik Loro Blonyo. Segmen pembeli yang menjadi target market dari toko Loro Blonyo adalah masyarakat umum yang mungkin membutuhkan batik untuk berbagai keperluan. Misalnya untuk kondangan, untuk seragam ke kantor atau sekolah, atau mungkin hanya untuk dikoleksi. Peminat umum ini mencari batik yang terjamin secara kualitas, memiliki corak dan desain yang khas, dan dijamin keasliannya.

b. Value Propositions

Blok value propositions menggambarkan kelebihan Toko Loro Blonyo yang menjadi daya jual, nilai tambah, dan kekuatan yang menjadikannya memiliki daya saing di pasar penjualan batik. Nilai-nilai yang menjadikan Toko Loro Blonyo unggul antara lain: (a) Produk kain dipesan langsung pada pengrajin, bukan tangan ketiga. (b) Produk fashion didesain langsung oleh pihak Loro Blonyo, untuk dikerjakan oleh penjahit dan konveksi, sehingga memiliki ciri khas yang khusus. (c) Karya kriya dan kerajinan dibuat secara handmade.

c. Channels

Demi memudahkan menjangkau seluruh customer Toko Loro Blonyo baik pelanggan yang pernah mengunjungi toko fisik ataupun yang hanya ingin membeli batik Loro Blonyo tanpa harus datang langsung ke lokasi toko di Brebes, maka diberikan layanan pembelian, informasi mengenai kegiatan, dan berbagai produk Toko Loro Blonyo melalui website e-commerce atau toko online dan media sosial.

d. Customer Relationships

Komponen ini menggambarkan semua kegiatan yang dilakukan oleh Loro Blonyo dalam menjaga hubungan dan kesetiaan pelanggan agar tertarik untuk terus berbelanja, selain itu digambarkan pula kegiatan yang dilakukan untuk menjangkau lebih banyak lagi calon customer. Salah satu kegiatan tersebut antara lain 
diskon dengan menggunakan kupon yang akan dikeluarkan pada setiap jangka waktu atau hari raya tertentu, pemberian informasi melalui blog, dan pelayanan langsung melalui WhatsApp.

e. Revenue Streams

Komponen revenue streams menggambarkan alur pendapatan yang menjadi pemasukan utama bagi Toko Loro Blonyo. Secara umum pendapatan tersebut didapatkan melalui sumber-sumber seperti penjualan produk batik, kerajinan, dan lukisan baik secara langsung maupun melalui daring.

f. Key Activities

Kegiatan utama yang dilakukan oleh Toko Loro Blonyo dalam mencapai atau menyediakan value proposition bagi produk-produknya. Dalam kegiatannya produk display ataupun mengunggahnya di online shop dan melalui jalur penjualan daring lainnya. Kegiatan lainya adalah promosi dan pemasaran produk.

g. Key Resources

Sumber Daya Penting menjadi bagian utama dari unsur penjualan produk Toko Loro Blonyo, karena inilah aset strategis yang menjadi dasar keunggulan value propositions: (a) Tempat yang disewa di lokasi wisata Rest Area Brebes. (b). Internet dan listrik. (c) Komputer atau laptop. (d). Karyawan tetap yang dipekerjakan untuk kegiatan penjualan langsung di lokasi serta karyawan yang dipekerjakan untuk kegiatan penjualan secara daring. (e) Karyawan honorer yang dipekerjakan pada akhir pekan untuk menampilkan cara pembuatan batik secara langsung di toko Loro Blonyo.

h. Key Partners

Loro Blonyo sebagai toko batik yang menyediakan produk langsung kepada pelanggan membutuhkan distributor bahan Baku, supplier barang dagangan, ataupun mitra strategis lain yang akan membantu dalam kegiatan jual beli sehari-hari. Beberapa key Partners yang dapat disebutkan yaitu: (a) Pengrajin batik khususnya pengrajin batik di kawasan yang dekat dengan Rest Area KM 260 yaitu yang berada di area Brebes, Cirebon, dan Pekalongan. (b) Konveksi pembuatan batik, produsen pakaian batik. (c) Pencetak bahan batik. (d) Pembuat lukisan dan kerajinan. (e) Ekspedisi pengiriman barang, semua perusahaan ekspedisi dapat menjadi parner.

i. Cost Structure

Cost structure atau struktur pembiayaan adalah pengeluaran yang harus diperhatikan oleh Loro Blonyo sebagai pos pembiayaan utama. Pengeluaran-pengeluaran tersebut adalah sebagai berikut: (a) Biaya sewa tempat di Rest Area KM.260 Brebes. (b) Gaji pegawai, termasuk biaya karyawan yang menangani web, media sosial, marketplace, dan blog Loro Blonyo. (c) Biaya sewa hosting dan domain untuk website. (d) Biaya internet dan listrik. (e) Biaya ekspedisi pengiriman barang dari dan ke lokasi penjualan di Rest Area KM.260 Brebes.

\subsection{Hasil Pemodelan E-Commerce}

Model e-commerce didesain dengan menggunakan diagaram UML. Hasil model yang dihasilkan diperlihatkan menggunakan use case diagram. Pada mode e-commerce yang dikembangkan, fungsi-fungsi yang ada pada model dibagi menjadi tiga kelompok utama yaitu Use Case Master, Use Case Transaksi dan Use Case Pelaporan. Beberapa use case tersebut dapat dilihat pada Gambar 3, 4 dan 5.

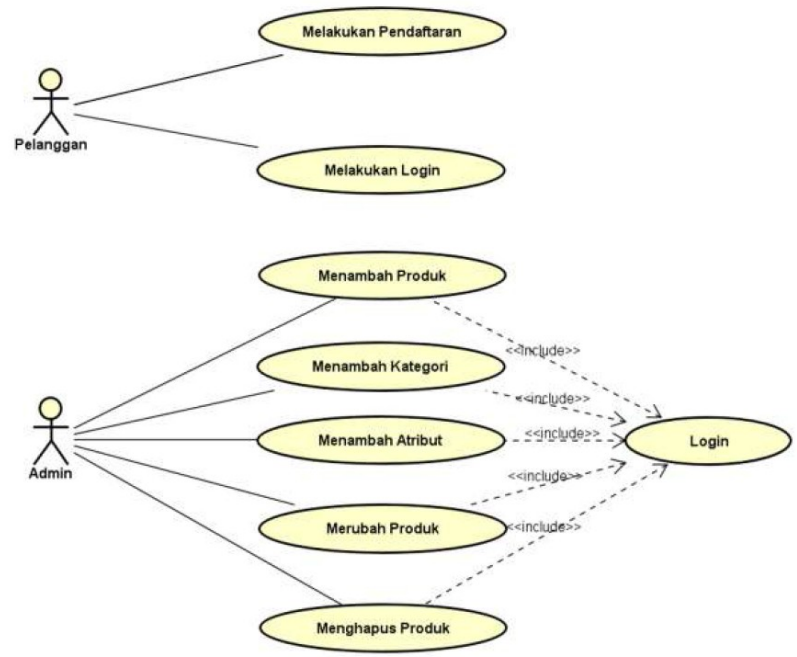

Gambar 3. Use Case Master 
Pada Gambar 3 diperlihatkan terdapat beberapa fungsi, yaitu Pendaftaran, Login, Menambah Produk, Menambah Kategori, Menambah Atribut, Merubah Produk dan Menghapus Produk. Penjelasan pada tiap fungsi adalah sebagai berikut:

Funsgi Pendaftaran merupakan fasilitas untuk melakukan pendaftaran sebelum melakukan traksaski pemesanan produk. Pendaftaran dapat dilakukan oleh calon penggan (aktor). Use case ini menjelaskan bagaimana pelanggan melakukan registrasi atau pendaftaran sebagai member. Pelanggan belum memiliki akses ke dalam halaman My-account dan belum dapat melakukan pembelian produk. Berikut ini tahapan yang harus dilakukan oleh calon pelanggan untuk pendaftaran (1) Pelanggan masuk ke situs LoroBlonyo.id dan memilih menu daftar. (2) Pelanggan mengisikan email, password pada form pendaftaran. (3) Sistem mengirimkan notifikasi pendaftaran melalui email. Setelah selesai, pelanggan sudah terdaftar pada situs LoroBlonyo.id dan bisa melakukan login untuk masuk ke halaman My-account.

Nama use case Nambah Produk, actor yang terlibat adalah Pelanggan. Use case ini merupakan menjelaskan bagaimana pelanggan dapat melakukan login untuk masuk ke halaman My-account. Sebelum melakukan login di situs LoroBlonyo.id. Tahapan dalam bekerja pada fungsi ini adalah adalah (1) Pelanggan mengakses situs LoroBlonyo.id dan masuk ke halaman My-account. (2) Pelanggan mengetikkan username dan password yang sesuai. Jika username atau password tidak cocok, sistem menampilkan pesan kesalahan. (3) Untuk keluar dari My-account, pelanggan dapat mengklik menu Logout. Setelah selesai, pelanggan sudah dapat login serta mengakses halaman My account dengan lengkap Nama use case adalah Menambah Produk. Actor yang terlibat adalah Admin. Deskripsi dari use case adalah menjelaskan bagaimana admin menambahkan produk.

Kondisi yang haru dipenuhi adalah tidak terdapat produk di website LoroBlonyo.id. Langkah kerja apada fungsi ini adalah (1) Admin melakukan login ke halaman backend atau dashboard. (2) Admin memilih menu woocommerce dan klik submenu product, pilih menu add new. (3) Setelah berada di halaman penambahan produk, admin menginput deskripsi, harga, tag, dan gambar dari produk. (4) Admin mengklik publish untuk mempublikasikan produk. Akhir dari fungsi ini ditandai dengan sudah terdapat produk yang djiual di website.

Nama use case adalah Menambah Kategori. Actor yang terlibat adalah Admin. Deskripsi dari use case adalah menjelaskan bagaimana admin menambahkan kategori produk. Kondisi yang harus terpenuhi adalahtidak terdapat kategori produk di website LoroBlonyo.id. Tahapan pengerjaan adalah (1) Admin melakukan login ke halaman backend atau dashboard. (2) Admin memilih menu woocommerce dan klik submenu product. (3) Admin memilih menu product categories, lalu mengisi nama kategori tersebut. (4) Admin mengklik add new categories untuk menyimpan kategori. Dondisi terakhir akan ditandari dengan terdapatnya kategori pada produk yang djiual.

Nama use case adalah Menambah Atribut. Actor yang terlibat Admin. Use case ini merupakan menjelaskan bagaimana admin menambahkan atribut warna dan ukuran pada produk. Syarat yang harus terpenuhi tidak terdapat variasi warna dan ukuran (jika ada) pada produk yang dijual di website LoroBlonyo.id. Cara kerja use case ini adalah (1) Admin melakukan login ke halaman backend atau dashboard. (2) Admin memilih menu woocommerce dan klik submenu product, lalu klik add new. (3) Admin mengklik variabel product, dan mengarahkan kursor ke menu variation. Silahkan diisi atribut yang diinginkan pada halaman produknya. (4) Admin mengklik tombol save untuk menyimpan atribut produk dan menampilkannya di halaman website LoroBlonyo.id. di akhir kondisi adalah sudah terdapat variasi atribut pada produk yang djiual.

Nama use case adalah Merubah Produk. Actor yang terlibat Admin. Use case ini menjelaskan bagaimana admin dapat merubah data produk. Syarat yang harus terpenuhi adalah terdapat data yang kurang sesuai pada data produk di website LoroBlonyo.id. Cara kerja adalah (1) Admin melakukan login ke halaman backend atau dashboard. (2) Admin memilih menu woocommerce dan klik sub menu product, pilih menu edit. (3) Setelah berada di halaman produk, admin mengubah deskripsi, harga, tag, dan gambar dari produk. (4) Admin mengklik update untuk mempublikasikan produk. Akhir kondisi ini Data produk yang djiual di website sudah sesuai.

Nama use case adalah Menghapus Produk. Actor yang terlibat Admin. Use case ini menjelaskan bagaimana admin menghapus produk. Syarat yang harus terpenuhi terdapat produk yang tidak lagi dijual di website LoroBlonyo.id. Cara kerja adalah (1) Admin melakukan login ke halaman backend atau dashboard. (2) Admin memilih menu woocommerce dan klik submenu product, pilih menu trash. Kondisi terakhir adalah produk sudah tidak lagi dijual di website.

Pada Gambar 4 diperlihatkan terdapat beberapa fungsi, yaitu Melakukan Pemesanan, Melakukan Konfirmasi Pembayaran, Melakukan Konfirmasi Terima Barang, Edit Status Pemesanan, Verifikasi Pembayaran dan Input No Resi. Penjelasan pada tiap fungsi adalah sebagai berikut:

Nama use case adalah Melakukan Pemesanan. Actor yang terlibat Pelanggan. Use case ini tentang bagaimana pelanggan memesan produk. Kondisi yang harus terpenuhi pelanggan belum memilih atau memesan produk. Tahapan pengerjaanya adalah (1) Pelanggan melakukan login di website LoroBlonyo.id, lalu membuka menu toko untuk memilih atau memesan produk. (2) Setelah memilih produk, pelanggan mengklik add to cart 
maka produk tersimpan ke dalam cart. (3) Setelah produk masuk ke dalam cart, pelanggan dapat memilih proceed to checkout. (4) Pada halaman checkout, pelanggan memasukkan alamat pengiriman, dan memilih metode pengiriman. (5) Klik place order untuk melakukan pemesanan. Kondisi akhir pelanggan sudah memilih dan memesan produk.

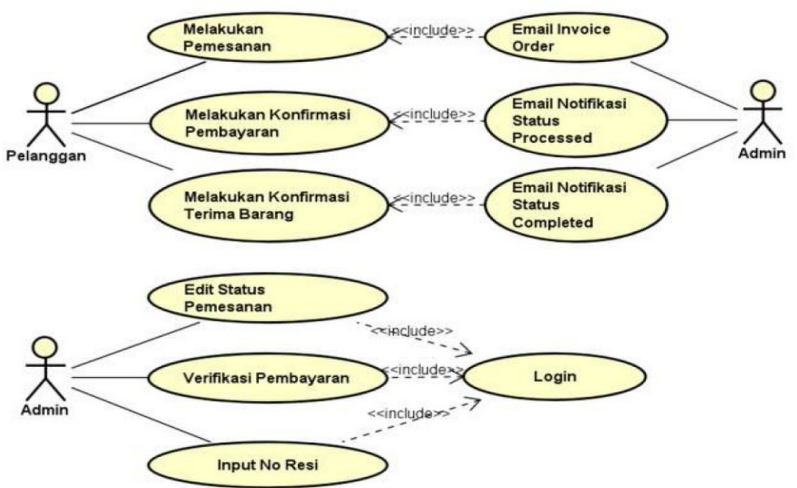

Gambar 4. Use Case Transasksi

Nama use case Melakukan Konfirmasi Pembayaran. Actor yang terlibat Pelanggan. Use case ini menjelaskan tentang bagaimana pelanggan melakukan konfirmasi pembayaran. Kondisi yang harus terpenuhi adalah pelanggan sudah memesan produk, mengirim transfer, namun belum mengunggah bukti transfer. Cara kerjnya adalah (1) Pelanggan melakukan login di website LoroBlonyo.id. (2) Pelanggan masuk ke menu My Account, kemudian memilih menu Orders. (3) Pelanggan dapat memilih menu Konfirmasi Pembayaran yang terdapat pada tabel atau pada menu di atas untuk menampilkan form konfirmasi. (4) Pelanggan mengisi formulir dan mengunggah bukti transfer. (5) Pelanggan mengklik tombol send. Kondisi akhir adalah pelanggan sudah menyelesaikan proses konfirmasi pembayaran dan mengirim bukti transfer.

Nama use case Melakukan Konfirmasi Terima Barang. Actor yang terlibat adalah Pelanggan. Use case ini menjelaskan tentang bagaimana pelanggan melakukan konfirmasi terima barang. Syarat untuk menjalankan fungsi ini adalah pelanggan sudah menerima produk, namun belum mengirimkan konfirmasi terima barang untuk mengubah status order. Cara kerja use case ini adalah (1) Pelanggan melakukan login di website LoroBlonyo.id. (2) Pelanggan memilih menu Konfirmasi Terima Barang pada sub-menu Konfirmasiuntuk menampilkan form. (3) Pelanggan mengisi form dan mengunggah bukti gambar produk. (4) Pelanggan mengklik tombol send. Kondisi akhir adalahAdmin telah mengubah status order dari pelanggan.

Nama use case Edit Status Pemesanan. Actor yang terlibat adalah Admin. Use case ini menjelaskan bagaimana admin mengubah status pemesanan produk oleh pelanggan. Kondisi yang harus terpenuhi adalah Admin belum mengubah status pemesanan produk oleh pelanggan. Cara kerja use case ini adalah (1) Admin melakukan login pada backend atau dashboard. (2) Admin memilih menu WooCommerce dan submenu Orders untuk membuka daftar pemesanan. (3) Admin memilih salah satu pesanan barang untuk masuk ke halaman detail pemesanan. (4) Pada halaman edit order, admin dapat memilih status yang dikehendaki pada kolom Status. (5) Selesaikan proses dengan memilih tombol Update. Akhir kondisi adalah Admin telah mengubah status order dari pelanggan.

Nama use case adalah Verifikasi Pembayaran. Actor yang terlibat adalah Admin. Use case ini menjelaskan bagaimana admin melakukan verifikasi konfirmasi pembayaran yang dilakukan oleh pelanggan. Kondisi yang harus terpenuhi adalah Admin belum melakukan verifikasi konfirmasi pembayaran yang sudah dikonfirmasi oleh pelanggan. Cara kerja adalah (1) Admin melakukan login pada backend atau dashboard. (2) Admin memilih menu Confirm Payment untuk membuka kiriman konfirmasi pembayaran oleh para pelanggan. (3) Admin membuka gambar pada kolom slip untuk memeriksa dan memverifikasi bukti transfer. (4) Jika data valid, admin mengubah status orders pelanggan dengan memilih approve pada kolom action. Akhir kondisi adalah Admin telah melakukan verifikasi konfirmasi pembayaran pelanggan dan mengubah status order.

Nama use case Input No Resi. Actor yang terlibat adalah Admin. Use case ini menjelaskan bagaimana admin menginformasikan nomor resi pengiriman barang kepada pelanggan. Kondisi yang harus terpenuhi adalah Admin belum menginformasikan nomor resi pengiriman kepada pelanggan. Cara kerja adalah (1) Admin melakukan login pada backend atau dashboard. (2) Admin memilih menu WooCommerce dan submenu Orders untuk membuka daftar pemesanan. (3) Admin memilih salah satu pesanan barang untuk masuk ke halaman detail pemesanan. (4) Pada halaman edit order, admin dapat mengisi nomor resi, tanggal pengambilan atau pengiriman 
barang melalui ekspedisi, dan mencentang pilihan order pick up jika produk sudah dikirimkan. (5) Selesaikan proses dengan memilih tombol Update. Akhir kondisi adalah Admin telah menginput dan menginformasikan nomor resi kepada pelanggan.

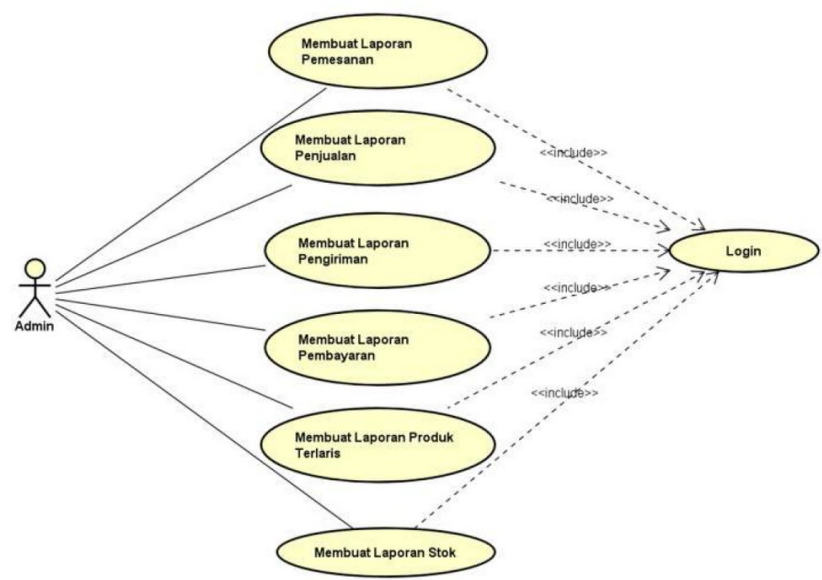

Gambar 5. Use Case Laporan

Pada Gambar 5 merupakan fungsi atau fasilitas untuk mencetak laporan yang dibutuhkan pihak manajemen. Beberapa laporan yang disediakan dalam model ini adalah Laporan Pemesanan, Laporan Penjualan, Laporan Pengiriman, Laporan Pembayaran, Laporan Produk Terlaris dan Laporan Stok Barang.

Nama use case Membuat Laporan Pemesanan, Membuat Laporan Penjualan, Membuat Laporan Pengiriman, Membuat Laporan Pembayaran. Actor yang terlibat Admin. Use case ini menjelaskan bagaimana admin membuat laporan pembayaran. Membuat Laporan Produk Terlaris dan Membuat Laporan Stok Produk. Actor yang terlibat Admin. Use case ini menjelaskan bagaimana admin membuat laporan stok produk. Syaratyang harus terpenuhi Admin belum membuat laporan stok. Cara kerjanya adalah (1) Admin melakukan login ke halaman backend atau dashboard. (2) Admin memilih menu Analytics dan klik sub menu Stock. (3) Admin melakukan pemilihan tanggal laporan. (4) Admin klik download untuk mencetak laporan. Akhri kondisi adalah Admin telah membuat laporan stok produk

\subsection{Implementasi E-Commerce Loro Blonyo}

Hasil dari pengembangan model e-commerce pada toko Loro Blonyo telah diimplementasikan di laman website https://loroblonyo.id/. Tampilan utama pada website Loro Blonyo dapat dilihat pada Gambar 6.

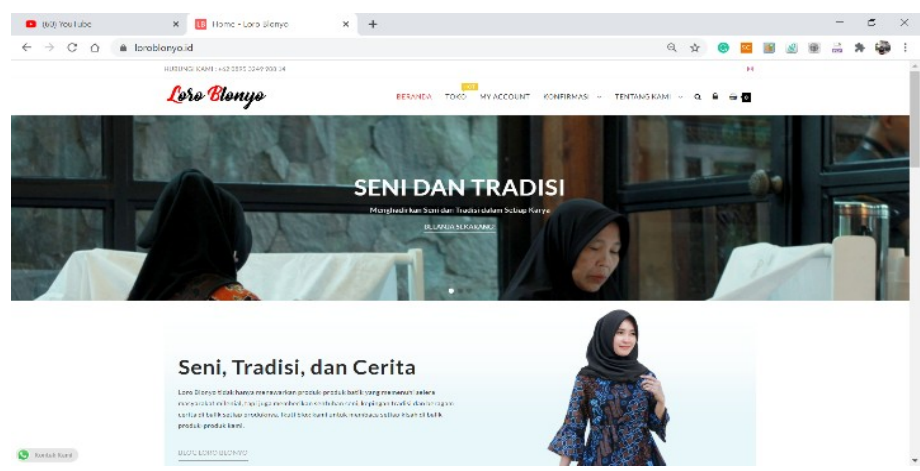

Gambar 6. Tampilan layar utama pada web site Loro Blonyo

Upaya untuk meningkatkan kinerja website website LoroBlonyo.id adalah dengan SEO. Penerapan SEO ini dapat cepat terindex oleh mesin pencari berdasarkan kata kunci tertentu dan bisa menembus halaman-halaman terdepan di mesin pencari. Strategi SEO yang dilakukan pada situs LoroBlonyo.id adalah strategi on-page dengan memanfaatkan plugin Yoast SEO sebagai salah alat untuk mengoptimalkan keyword, keyphrase atau kata kunci untuk meraih posisi terbaik pada mesin pencari khususnya Google. Hasil dari kinerja Yoast SEO terbukti cukup cepat menempatkan alamat situs di halaman hasil pencarian search engine Google. 
Optimalisasi Yoast SEO dapat memanfaatkan Yoast SEO secara tepat guna, maka perlu dilakukan optimalisasi di setiap halaman situs LoroBlonyo.id baik itu pada halaman post, pages, ataupun halaman produk. Optimalisasi yang dilakukan meliputi penentuan keyphrase khas tiap halaman, optimalisasi judul, permalink, meta description, alt pada image dan tentunya optimalisasi pada konten itu sendiri.

Berikut adalah deskripsi penerapan penting yang harus dilakukan dan diperhatikan pada setiap posting produk agar memperoleh posisi yang diinginkan pada mesin pencari:

a. Focus Keyphrase, keyphrase atau kata kunci merupakan fokus pencarian di search engine dan menjadi perhatian utama optimalisasi.

b. Slug Slug adalah bagian dari URL yang menjadikan halaman situs tersebut khas dan unik. Misalnya www.loroblonyo.id/flatshoes-lurik-biru, maka bagian slugnya adalah flatshoes-lurik-biru. Bagian ini sebaiknya disamakan atau mengandung keyphrase.

c. Meta Description, meta description digunakan untuk memberikan keterangan singkat yang akan dimuat di hasil pencarian dan merupakan keterangan pertama yang akan dijumpai oleh pencari atau user di search engine. Agar keseluruhan paragraf dapat terbaca di mesin pencari, maka disarankan untuk membuat sebuah paragraf singkat di bawah 156 karakter.

d. Text Length, text length atau panjang teks adalah jumlah kata minimal yang disarankan untuk satu post atau keterangan produk. Minimal jumlah kata tersebut berkisar pada 250-300 kata.

e. Outbound Links Outbound links merupakan link dari dalam post atau keterangan produk yang diarahkan menuju situs selain LoroBlonyo.id

f. Internal Links Internal Links adalah link ke dalam atau link yang diarahkan menuju situs itu sendiri. Dalam hal ini diterapkan dengan meletakkan link yang mengarah ke halaman home yaitu www.LoroBlonyo.id.

g. Keyphrase in Introduction Keyphrase in Introduction adalah penempatan keyphrase pada pembuka paragraf atau alinea pertama pada post atau keterangan produk.

h. Keyphrase Length, Keyphrase Length atau panjang keyphrase yang disarankan adalah maksimal sebanyak empat kata.

i. Keyphrase in Meta Description Keyphrase in Meta Description atau penempatan keyphrase di Meta Description adalah salah satu hal yang disarankan.

j. $\quad$ Previously Used Keyphrase Previously Used Keyphrase atau penggunaan kembali keyphrase pada situs yang sama tidak disarankan. Sehingga diharapkan dapat menggunakan kata kunci yang benar-benar unik dan baru di setiap post-nya.

k. Image Alt Attributes Penempatan atribut keterangan pada gambar yang disematkan pada post atau produk.

1. Keyphrase in Title Keyphrase in Title adalah penempatan kata kunci pada judul post atau keterangan produk.

m. SEO Title Width Judul post atau keterangan produk sebaiknya tidak terlalu panjang karena jika terlalu panjang akan terpotong pada saat ditampilkan pada mesin pencari. 14) Keyphrase Density Keyphrase Density merupakan banyaknya jumlah kata kunci dalam satu post atau keterangan produk, sebaiknya kata kunci muncul minimal dua kali dalam satu post.

\subsection{Pengujian model E-Commerce Loro Blonyo}

Pengujian model e-commerce Loro Blonyo yang dilakukan adalah pengujian langsung ke user. Pengujian yang dilakukan dibagi menjadi dua bagian, yang pertama pengujian terhadap semua fungsi yang ada dan pengujian kedua adalah meminta pendapat atau penilaian dari user. Pengujian terhadap semua fungsi pada model e-commerce Loro Blonyo adalah mencoba dengan menggunakan data sebenarnya yang dilapangan. Pada pengujian ini mendapatkan bahwa semua fungsi yang ada dapat berjalan dengan baik. Hasil pengujian ini dapat dilihat pada laman https://loroblonyo.id/.

Kemudian, pengujian yang kedua adalah meminta pendapat atau penilaian dari user. Hasil dari pengujian ini didapatkan bahwa model e-commerce yang dikembangkan sudah sesuai dengan kebutuhan di lapangan. Model e-commerce yang dikembangkan dapat menyelesaikan masalah yang ada, Walaupun belum sepenuhnya semua masalah dapat diselesaikan. Akantetapi, pada saat ini model e-commerce sudah berjalan dengan baik.

\section{KESIMPULAN}

Hasil penelitian yang telah dilakukan adalah tersbentuknya model e-commerce berbasis web pada toko Loro Blonyo. Model e-commerce yang dikembangkan dapat berfungsi dengan baik dan dapat diterima oleh user dengan baik. Model e-commerce yang dikembangkan dapat memberikan kemudahan dalam akses karena 
tersedianya penjualan secara luring dan daring. Selain itu, model e-commerce yang dikembangkan dapat memperluas jangkauan pasar atau pelanggan.

Penggunaan sistem melalui situs web e-commerce memudahkan admin dalam mengatur dan mengumpulkan laporan pemesanan, laporan penjualan, laporan pembayaran, laporan pengiriman, laporan stok dan laporan produk terlaris secara daring untuk kemudian diberikan kepada pihak pengelola Toko Loro Blonyo. Dengan adanya laporan-laporan yang dibutuhkan tersebut diharapkan pengelola kemudian dapat memanfaatkannya untuk pengambilan keputusan dalam bidang pemasaran dan penjualan.

\section{DAFTAR PUSTAKA}

[1] A. Guntoro, and G. Triyono, "Penerapan E-Commerce Berbasis Content Management System (CMS) dengan Metode Business Model Canvas (BMC) pada Konveksi Gamis Tawakal,” IDEALIS: InDonEsiA journaL Information System, 2(5), 2019, 16-22.

[2] J. G. Rizal, https://www.kompas.com/tren/read/2020/08/11/102500165/pandemi-covid-19-apa-sajadampak-pada-sektor-ketenagakerjaan-indonesia-?page=all, 2020.

[3] I. I. Prasetya, and A. Widjaja, "Penerapan E-Commerce Berbasis Wordpress untuk Penjualan pada Distro ID Clothing,” IDEALIS: InDonEsiA JournaL Information System, 2(6), 2019, 307-312.

[4] W. A. Putra, and L. L. Hin, "Penerapan E-Commerce untuk Memperluas Jangkauan Pasar Pada Toko Batik Marissa Dengan Menggunakan Metode Business Model Canvas,” IDEALIS: InDonEsiA JournaL Information System, 2(6), 2019, 286-292.

[5] W. D. Cahyo, and G. Triyono, "Penerapan E-Commerce berbasis Content Management System (CMS) untuk Penjualan Pakaian Pada Toko Chipindwear," IDEALIS: InDonEsiA JournaL Information System, 2(6), 2019, 435-411

[6] W. Diphayana, “Perdagangan Internasional.” Yogyakarta: Deepublish, 2018.

[7] N. F. S. Hasyim, "Technopreneurship Membentuk Karakter Entrepreneur Muda Yang Sukses," Yogyakarta: Deepublish, 2016.

[8] H. Himawan, A. Saefullah, and S. Santoso, "Analisa dan Perancangan Sistem Informasi Penjualan Online (E-Commerce) pada CV Selaras Batik Menggunakan Analisis Deskriptif,” Scientific Journal of Informatics, 1(1), 2014, 53- 63.

[9] M. Pradana,. “Klasifikasi Bisnis E-Commerce Di Indonesia,” Modus, 27(2), 2015, 163-174.

[10] A. Osterwalder, and Y. Pigneur, "Business Model Generation: A Handbook for Visionaries, Game Changers, and Challengers," Hoboken: John Wiley \& Sons, 2010.

[11] R. Abdulloh, “Trik Membuat CMS Website Dari Nol,” PT. Elex Media Komputindo, 2016.

[12] A. Veglis, and D. Giomelakis, "Search Engine Optimization. Multidisciplinary Digital Publishing Institute,”, 2020. 